\title{
Mensenchymal stem cells can delay radiation-induced crypt death: impact on intestinal CD44 ${ }^{+}$fragments
}

\author{
Peng-Yu Chang ${ }^{1,2} \cdot$ Xing Jin $^{3}$ • Yi-Yao Jiang ${ }^{4}$ - Li-Xian Wang ${ }^{5}$. \\ Yong-Jun Liu ${ }^{6} \cdot$ Jin Wang ${ }^{2}$
}

Received: 26 May 2015 / Accepted: 13 October 2015 / Published online: 27 November 2015

(C) The Author(s) 2015. This article is published with open access at Springerlink.com

\begin{abstract}
Intestinal stem cells are primitive cells found within the intestinal epithelium that play a central role in maintaining epithelial homeostasis through self-renewal and commitment into functional epithelial cells. Several markers are available to identify intestinal stem cells, such as Lgr5, CD24 and EphB2, which can be used to sort intestinal stem cells from mammalian gut. Here, we identify and isolate intestinal stem cells from C57BL/6 mice by using a cell surface antigen, CD44. In vitro, some CD44 ${ }^{+}$crypt cells are capable of forming "villus-crypt"-like structures (organoids). A subset strongly positive for CD44 expresses high levels of intestinal stem-cell-related genes, including Lgr5, Bmil, Hopx, Lrig1,
\end{abstract}

This study was funded by The National Natural Science Funds of China (grants: 81372929 and 81502751).

Electronic supplementary material The online version of this article (doi:10.1007/s00441-015-2313-6) contains supplementary material, which is available to authorized users.

Yong-Jun Liu

andyliuliu2001@yahoo.com.cn

Jin Wang

jin.d.wang@gmail.com

1 Department of Radiation Oncology, The First Bethune Hospital of Jilin University, Changchun 130021, People's Republic of China

2 Changchun Institute of Applied Chemistry, Chinese Academy of Sciences, Changchun 130000, People's Republic of China

3 Ever Union Biotechology, Tianjin 300162, People's Republic of China

4 Department of Cardiac Surgery, TEDA International Cardiovascular Hospital, Tianjin 300000, People's Republic of China

5 Tianjin Institute of Industrial Biotechnology, Chinese Academy of Sciences, Tianjin 300300, People's Republic of China

6 Alliancells Bioscience, Tianjin 300300, People's Republic of China
Ascl2, Smoc2 and Rnf43. Cells from this subset are more capable of developing into organoids in vitro, compared with the subset weakly positive for CD44. However, the organoids are sensitive to ionizing irradiation. We investigate the specific roles of mesenchymal stem cells in protecting organoids against radiation-induced crypt death. When co-cultured with mesenchymal stem cells, the crypt domains of irradiated organoids possess more proliferative cells and fewer apoptotic cells than those not co-cultured with mesenchymal stem cells. $C d 44 v 6$ continues to be expressed in the crypt domains of irradiated organoids co-cultured with mesenchymal stem cells. Our results indicate specific roles of mesenchymal stem cells in delaying radiation-induced crypt death in vitro.

Keywords Mesenchymal stem cell $\cdot$ CD44 .

Radiation-induced death · Organoids · Crypt domains

\section{Introduction}

In mammals, the intestinal epithelium represents a tissue that self-renews for an entire lifetime. Typically, the intestinal epithelium requires a period of 4-5 days for one complete turnover (van der Flier and Clevers 2009). Homeostasis in the intestinal epithelium is accurately controlled by the proliferation of intestinal stem cells (ISCs) and their commitment into functional epithelial cells.

Currently, two pools of ISCs are acknowledged to occur within the crypts (Li and Clevers 2010). Herein, the $\operatorname{Lgr} 5^{+}$ ISCs located at the basement of crypts (termed "crypt base columnar [CBC] stem cells") represent a population of cells that maintain epithelial homeostasis under intact conditions (Barker et al. 2007). The exact duration of cell-cycling in CBC stem cells is $21.5 \mathrm{~h}$ (Schepers et al. 2011). When dividing, the parental DNA strands in the CBC stem cells 
are randomly segregated into their progeny (Schepers et al. 2011). Some cells will competitively bind to the surfaces of Paneth cells to keep their "stemness" (Snippert et al. 2010). The rest, without provisions from Paneth cells, will develop into transit-amplifying (TA) progenitors that will replenish the apoptotic cells by differentiating into functional cells along the villus-crypt axis (Snippert et al. 2010). In contrast to CBC stem cells, slow-cycling ISCs (termed "reserve ISCs"), which are positive for Bmi1, Lrig1, Hopx, or mTERT at the 4+ position of the crypts, represent a population of cells that undertake epithelial reversion upon intestinal injuries through their direct commitment to functional epithelial cells or through their conversion into $\mathrm{CBC}$ stem cells (Sato and Clevers 2013; Tian et al. 2011). Similarly, Dl11 ${ }^{+}$TA progenitors are capable of reprogramming themselves into $\mathrm{CBC}$ stem cells in order to promote epithelial regeneration (van Es et al. 2012).

However, any stimuli altering the genomic stability of ISCs will interrupt the epithelial homeostasis. For example, mutation in the Apc gene will lead to persistent activation of $\beta$ catenin/Tcf signaling pathway, resulting in a wild proliferation of CBC stem cells and subsequent neoplastic formation in the gut (Morin et al. 1997). Moreover, the deletion of thymineguanine in the 3' untranslated region of $C d 24$ gene in ISCs contributes to increased susceptibility to Crohn's disease (Van Limbergen et al. 2015). Thus, an investigation of ISC characteristics should improve public awareness of the pathogenesis of such diseases. In this context, Sato et al. (2009) first established a three-dimensional (3D) culture system that mimicked the development of CBC stem cells in vivo; one single CBC stem cell was capable of forming into a "villus-crypt"like structure (termed "organoids" below). Moreover, these organoids can be repeatedly expanded for up to 1 year (Sato et al. 2009). Based on these encouraging data, two studies were separately carried out to evaluate the therapeutic potentials of organoids on epithelial injuries in colon (Jung et al. 2011; Yui et al. 2012). The results showed that these organoids contributed significantly to epithelial regeneration, which depended on their long-lived potential to repair injured epithelium (Jung et al. 2011; Yui et al. 2012). Hence, regenerative therapy involving the use of ISCs will be an alternative option for managing intestinal injuries (Sato and Clevers 2013).

Nowadays, C57BL/ $6^{\text {lgr5-eGFP-IRES-CreERT2 }}$ reporter mice are the most popular sources for isolating $\mathrm{CBC}$ stem cells. Furthermore, some wild-type hosts are still an option for the isolation of ISCs. For example, the surface antigens CD24 or EphB2 have been reported to be candidates for the isolation of ISCs from murine or human gut (von Furstenberg et al. 2011; Sato et al. 2011a). Additionally, ISCs are reported to exist in the side-population (SP) of epithelial cells, as indicated by scatter diagrams obtained by using the fluorescenceactivated cell sorting (FACS) technique (von Furstenberg et al. 2014). In addition to these encouraging results, some evidence suggests that the $C d 44$ gene is a target of the Wnt/ $\beta$-catenin signaling pathway responsible for proliferation in $\mathrm{CBC}$ stem cells and the maturation of Paneth cells (van der Flier and Clevers 2009; Zeilstra et al. 2008, 2014; Wielenga et al. 1999). On this basis, we speculated that CBC stem cell proliferation will be accompanied by high levels of $C d 44$ gene expression. To test this hypothesis, we attempted to isolate ISCs from wild-type mice (strain: C57BL/6) by using CD44 antibody. Our results primarily showed that ISCs existed with crypt cells which had a high expression of $C d 44$, indicating that CD44 is a candidate for marking ISCs in murine gut. Moreover, the CD $44^{+}$ISCs resembled CBC stem cells. In addition, our previous findings suggested that the infusion of human adipose-derived mesenchymal stem cells (hAd-MSCs) could accelerate epithelial regeneration in irradiated intestine (Chang et al. 2013). In the present study, hAd-MSCs were used to investigate their specific roles in minimizing epithelial injuries through the co-culture of these cells with organoids. Relevant results showed that MSCs were capable of delaying radiation-induced crypt death.

\section{Materials and methods}

\section{Mice}

Male juvenile C57BJ/6 mice (6 weeks old) of an inbred strain and specific pathogen-free (SPF) level were provided by the Laboratory Animal Institute of the Chinese Academy of Military Medical Science (Beijing, China). The mice were housed in an authorized SPF-level animal room of Alliancells Bioscience (Tianjin, China). The study protocols were consistent with good animal practices under approval from our local animal care and use committee.

\section{Crypt fragment isolation and culture}

As described by Sato et al. (2009), the whole small intestine was isolated from C57BJ/6 mice and was split in a longitudinal direction. The intestine was washed repeatedly in prechilled D-Hanks buffer ( $\mathrm{pH}$ 7.4) to remove feces. The villi were then slightly scraped by using a sterilized coverslip and the intestinal tissue was cut into small pieces. The fragments were placed into a 50-ml tube (Corning, USA) and washed with pre-chilled D-Hanks buffer ( $\mathrm{pH}$ 7.4). Once the fragments had settled down to the bottom of the tube, $30 \mathrm{ml}$ isolationbuffer ( 2 mM EDTA in D-Hanks buffer) was added to the tube to suspend the fragments once again. Thereafter, the fragments were incubated on ice for $30 \mathrm{~min}$ with rotation. After incubation, the supernatant was removed and $30 \mathrm{ml}$ pre-chilled DHanks buffer ( $\mathrm{pH}$ 7.4) was added to the tube with agitation in order to release the crypt fragments. The suspension was then passed through a $70-\mu \mathrm{m}$ strainer (BD Bioscience, Franklin 
Lakes, N.J., USA) and the filtrate was collected in a $1 \%$ bovine serum albumin (BSA)-coated 50-ml tube (Corning). Subsequently, the suspension was centrifuged at $1000 \mathrm{rpm}$ for $5 \mathrm{~min}$ and the supernatant was removed carefully. Unavoidably, blood cells or adipocytes were contained within the collected crypt fragments. To exclude them by their weights, the crypt fragments had to be washed with $10 \mathrm{ml}$ basal culture medium (BCM) and then centrifuged at $500 \mathrm{rpm}$ for $2 \mathrm{~min}$ in a $15-\mathrm{ml}$ tube (Corning, USA) two or three times. After centrifugation, the crypt fragments at the bottom of the tubes were of high purity. These fragments were carefully suspended by using growth-factor-reduced phenolred-free Matrigel (BD Bioscience) at a ratio of 500 crypts per $50 \mu \mathrm{l}$ Matrigel. All procedures were processed on ice to prevent the Matrigel from heat-induced solidification. Thereafter, $50 \mu \mathrm{l}$ Matrigel containing crypt fragments were added into each well of a 24-well plate in order to create circles of Matrigel at $37{ }^{\circ} \mathrm{C}$. Then, $500 \mu \mathrm{l}$ crypt culture medium (CCM) was supplied to each well for culture at $37{ }^{\circ} \mathrm{C}$ under a humid atmosphere with $5 \% \mathrm{CO}_{2}$. The medium was changed every 4-6 days. Of note, CCM should be made $30 \mathrm{~min}$ before crypt plating. The CCM contained $1 \times$ Glutamax (Invitrogen, USA), $1 \times$ HEPES (Invitrogen), $100 \mathrm{U} / \mathrm{ml}$ penicillin (Invitrogen), $100 \mu \mathrm{g} / \mathrm{ml}$ streptomycin (Invitrogen), $1 \times \mathrm{N} 2$ (Invitrogen), 1×B27 (Invitrogen), $1 \mathrm{mM} \mathrm{N}$-acetylcysteine (Sigma-Aldrich, USA), $100 \mathrm{ng} / \mathrm{ml}$ epithelial growth factor (EGF; Peprotech, USA), $100 \mathrm{ng} / \mathrm{ml}$ Noggin (Peprotech, USA) and $1000 \mathrm{ng} / \mathrm{ml} \mathrm{R}$-spondin (Peprotech, USA) in Advanced-DMEM/F12 medium (Invitrogen). The BCM contained 1×Glutamax (Invitrogen), 1× HEPES (Invitrogen), $100 \mathrm{U} / \mathrm{ml}$ penicillin (Invitrogen) and $100 \mu \mathrm{g} / \mathrm{ml}$ streptomycin (Invitrogen) in Advanced-DMEM/F12 medium (Invitrogen). The reagents were stored according to the manufacturers' instructions.

\section{Isolation and culture of CD44 ${ }^{+}$ISCs}

As mentioned above, the isolated crypts were incubated in $1 \mathrm{ml}$ single-cell released medium (SRM; BCM plus $1 \times \mathrm{N} 2$, $1 \times \mathrm{B} 27,10 \mu \mathrm{M}$ Y-27632 dihydrochloride, $0.1 \% \mathrm{BSA}$ ) for $30 \mathrm{~min}$ at room temperature with frequent rotation to release the cells. Importantly, repeated pipetting every $10 \mathrm{~min}$ was essential to avoid the formation of cell-clusters during incubation. Subsequently, the cell suspension was passed through a $40-\mu \mathrm{m}$ strainer (BD Bioscience) and then though a $20-\mu \mathrm{m}$ strainer (Millipore). The filtrate was collected for further washes in SRM (3 times).

During incubation for single cell releasing, rabbit antimouse CD44 primary antibody (Santa Cruz Biotechnology, Santa Cruz, Calif., USA) was added to SRM at the ratio of 1:50 (w/v). After a filtering step, the cells were washed in SRM (3 times) to remove unconjugated primary antibody. Thereafter, the number of viable single-cells was determined and microbead-conjugated goat anti-rabbit IgG secondary antibody (Milteny) was diluted in SRM at a ratio of 1:4 (v/v). The cells were incubated in SRM containing $20 \%$ secondary antibody on ice for $15 \mathrm{~min}$ and then passed through the separator column. The filtrate was discarded and the cells in the separator column were collected (Positive selection). Batches each with 100 single-cells were suspended in $10 \mu \mathrm{l}$ Matrigel containing $1 \mu \mathrm{M}$ Jagged-1 (Ana Spec) and were plated on 96well plates supplemented with $100 \mu$ intestinal stem cell culture medium (ICM) containing $10 \mu \mathrm{M} \mathrm{Y}-27632$ dihydrochloride (Sigma-Aldrich, USA) and $100 \mathrm{ng} / \mathrm{ml} \mathrm{Wnt-}$ 3a (Peprotech, USA) diluted in CCM. Cytokines were supplied every 2 days after the cells had been plated and the medium was completely changed every $4-6$ days. The Y-27632 dihydrochloride and Wnt-3a peptide were present only during the first 6 days of cell culture. When Paneth cells were observed under an inverted microscope, the ICM could be seen to be completely replaced by CCM.

\section{Fluorescence-activated cell sorting}

To analyze the phenotype of the $\mathrm{CD} 44^{+}$crypt cells, rat antimouse CD31-phycoerythrin (PE), CD34-PE, CD44allophycocyanin (APC) and CD45-APC antibodies were used. IgG2b-APC and IgG2a-PE were employed as isotypes. All antibodies were purchased from eBioscience (San Diego, Calif., USA). All experimental procedures were performed in accordance with the manufacturer's instructions. In addition, the CD44- CD $44^{\mathrm{hi}+}$ and CD44 $4^{\text {low }+}$ cells were separately sorted by using the FACS method on a MoFlo XDP (Beckman Coulter, Brea, Calif., USA).

\section{Histological analysis}

Immunohistochemical (IHC) staining was used to determine the distribution of $\mathrm{Lgr}^{+}$ISCs and CD $44^{+}$cells and of the $\mathrm{Ki} 67^{+}$proliferative cells in the intestinal epithelium. In detail, paraffin-embeded sections were examined by IHC staining. First, sections $(4 \mu \mathrm{m})$ were dewaxed and rehydrated in dimethylbenzene followed by a gradient of alcohol. Then, the sections were immersed in $0.3 \%$ hydrogen peroxide solution to block endogenous peroxides. Next, antigen retrieval was carried out in $1 \times$ sodium citrate solution. Thereafter, sections were incubated with goat serum for $30 \mathrm{~min}$ at room temperature to block non-specific antigen-binding sites. Before this step, if the antigen was expressed in the nucleus, the cell membranes in sections had to be ruptured by incubation with $0.25 \%$ Triton X-100 (Roche, Basel, Switzerland) solution for $10 \mathrm{~min}$ at room temperature. Primary antibodies, including rabbit anti-mouse Lgr5 (Santa Cruz Biotechnology, Santa Cruz, Calif., USA), rabbit anti-mouse CD44 (Santa Cruz) and rabbit anti-mouse Ki67 (Abcam, Cambridge, Mass., USA), were diluted according to the manufacturers' 
instructions. The diluted primary antibodies were incubated with sections overnight at $4{ }^{\circ} \mathrm{C}$. Thereafter, goat anti-rabbit IgG secondary antibody (Abcam) was used for detecting positive cells in the section after an incubation time of $2 \mathrm{~h}$ at $37{ }^{\circ} \mathrm{C}$. The cell nucleus was stained by using hematoxylin (Sigma-Aldrich). Imaging was carried out by means of a BX51WI microscope (Olympus, Japan).

Immunocytochemical (ICC) staining was used to evaluate the distribution of $\mathrm{CD} 44^{+}$cells and $\mathrm{Ki} 67^{+}$proliferative cells in organoids and the differentiation of $\mathrm{CD} 44^{+}$ISCs into epithelial cells. In detail, the organoids were incubated with $4 \%$ paraformaldehyde solution for $30 \mathrm{~min}$ at $37^{\circ} \mathrm{C}$, mechanically removed from Matrigel into an EP tube (Corning) and incubated with blocking solution for $30 \mathrm{~min}$ at room temperature. Before this step, if the antigens were expressed in the nucleus, $0.25 \%$ Triton X-100 (Roche) solution was used for permeabilization for $5 \mathrm{~min}$ at room temperature. Diluted primary antibodies were added to the EP tubes at the concentrations recommended by manufacturers. Incubation was carried out overnight at $4{ }^{\circ} \mathrm{C}$. After the primary antibodies had been discarded and following two to three washes in phosphatebuffered saline ( $\mathrm{pH}$ 7.4), diluted secondary antibodies were added to the EP tubes. The incubation duration was $2 \mathrm{~h}$ at $37{ }^{\circ} \mathrm{C}$. The cell nuclei were stained with 4,6-diamidino-2phenylindole (DAPI; Invitrogen). Imaging was carried out by means of an SP5-II confocal microscope (Leica, Germany).

Transferase-mediated deoxyuridine triphosphate-biotin nick end labeling (TUNEL)-staining was used to detect apoptotic cells, both in vitro and in vivo. The in situ cell death detection kit, POD (Roche), was employed in the present study. All experimental processes were performed according to the manufacturer's instructions. Imaging was carried out separately by means of a BX51WI microscope (Olympus, Japan) and an SP5-II confocal microscope (Leica, Germany).

Transmission electron microscopy (HITACHI, Japan) was used to analyze the subcellular structures of CD44 ${ }^{+}$ISC-derived organoids. The organoids were fixed with $2.5 \%$ glutaraldehyde for $2 \mathrm{~h}$. Thereafter, dehydration of the samples was carried out via a gradient of acetone solutions. The dehydrated organoids were embedded in Epon 812 and sectioned at a thickness of $50 \mathrm{~nm}$. The sections were stained with $5 \%$ uranyl acetate, lead citrate and $3 \%$ potassium phosphotungstate.

\section{Chemotaxis of MSCs}

MSCs from human adipose tissue were purchased from SciencCell Research Laboratories (Carlsbad, Calif., USA). To investigate the specific roles of MSCs on irradiated organoids, a co-culture system was established. The crypt fragments were cultured for 7 days in a 12-well transwell plate before receiving irradiation. When the crypt fragments developed into organoids, on the 7 th day the organoids were irradiated by using an RS-2000 Pro Biological Irradiator (Rad-Source, Suwanee, Ga., USA). Immediately, MSCs of passage 6 were plated onto the upper mesh of $12-\mu \mathrm{m}$ bore diameter. Before this step, the MSCs had been labeled by using CM-Dil cell tracker (Invitrogen), a lipophilic marker, according to the manufacturer's instructions.

\section{Real-time polymerase chain reaction}

Semi-quantitative reverse transcription (RT) followed by the polymerase chain reaction (PCR) was used to evaluate ISCrelated gene expression by the $\mathrm{CD} 44^{-}, \mathrm{CD} 44^{\text {low }}$ and $\mathrm{CD} 44^{\mathrm{hi}+}$ subpopulations. The total RNA in $5 \times 10^{5}$ of sorted cells was extracted by using an RNA Extraction Kit (Takara-bio, Shiga, Japan). Thereafter, $1 \mu \mathrm{g}$ total RNA from each sample was used for the synthesis of first-strand cDNA by using an RTPCR Kit (Takara). Total cDNA was then added to primers for mouse Lgr5, Bmi1, Lrig1, mTert, Hopx, Ascl2, Rnf43, Smoc2 and Prominin-1. Additionally, mouse actin primers were used as controls. The sequences of these primers are listed in Supplemental Table S1. Semi-quantitative PCRs were performed by using SYBR Green I Taqman probes (Roche) in 40 amplifying cycles in ABI 7500 Fast equipment (Beckman Coulter).

RT-PCR was used for comparing the $C d 44 v 6$ expression levels of irradiated organoids with or without MSC intervention. All experimental procedures were in accordance with the above information. The sequences of primers for $C d 44 v 6$ are listed in Supplemental Table S1.

\section{Statistical analysis}

Data were analyzed by using SPSS 17.0 software (SPSS, Chicago, Ill., USA) and are shown as means \pm standard deviation (SD). The paired $t$-test was performed to compare data between two groups. Statistical significance was defined as $P \leq 0.05$.

\section{Results}

\section{$\mathrm{CD}^{+} 4^{+}$cells are mainly located at putative positions of ISCs within crypts}

ISCs are known to be uniformly located within the crypt domain in mammals. The determination of ISCs in vivo relies on two rules: the expression of the ISC-related marker and location at putative positions of ISCs in crypts (Clevers 2013). For example, the $\mathrm{CBC}$ stem cells highly express the Wnt-targeted gene, $\operatorname{Lgr} 5$ and are located between two Paneth cells (Barker et al. 2007). Meanwhile, some $\operatorname{Lgr} 5^{+}$ISCs are also located at the $4+$ position of the crypt (Barker et al. 2007). 
To determine the specific distribution of $\mathrm{CD} 44^{+}$putative ISCs in the crypts, the $\mathrm{Lgr}^{+}$ISCs were set as positive controls (Fig. 1a, b). As shown in Fig. 1c, d, some cells that were located at the crypt basement and intermingled with Paneth cells (containing granules in plasma) were strongly positive for CD44. The in vitro study also indicated that the cells positive for CD44 were mainly located at the crypt basement, in addition to the 4+ position (Fig. 1e-n). Since the $\mathrm{CD} 44^{+}$cells were mainly located at the putative positions of ISCs within the crypt, we speculated that the ISCs existed in the population of CD $44^{+}$crypt cells.

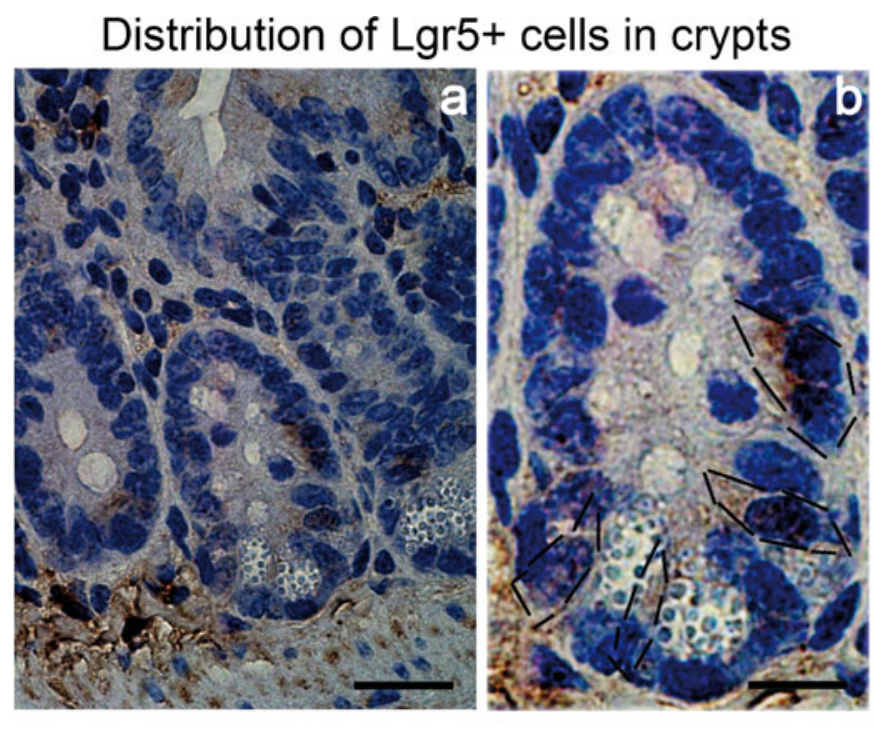

\section{One population of ISCs exists in $\mathrm{CD}_{4} 4^{+}$crypt cells}

To test the above hypothesis, we first isolated the CD $44^{+}$crypt cells from the small intestine by using a microbead-based sorting technique. FACS analysis showed that the purity of these sorted cells was extremely high ( $99 \%$; Fig. 2a"”'). The results of the phenotypic analysis showed that these CD $44^{+}$crypt cells were negative for CD31, CD34 and CD45, indicating that these cells did not originate from the endothelial and hemapoietic lineages (Fig. 2a-a"'”). Next, we cultured these cells in our 3D-system. The CD44- crypt cells were set as controls. Compared with the $\mathrm{CD} 44^{-}$controls, some

\section{Distribution of CD44+ cells in a organoid}
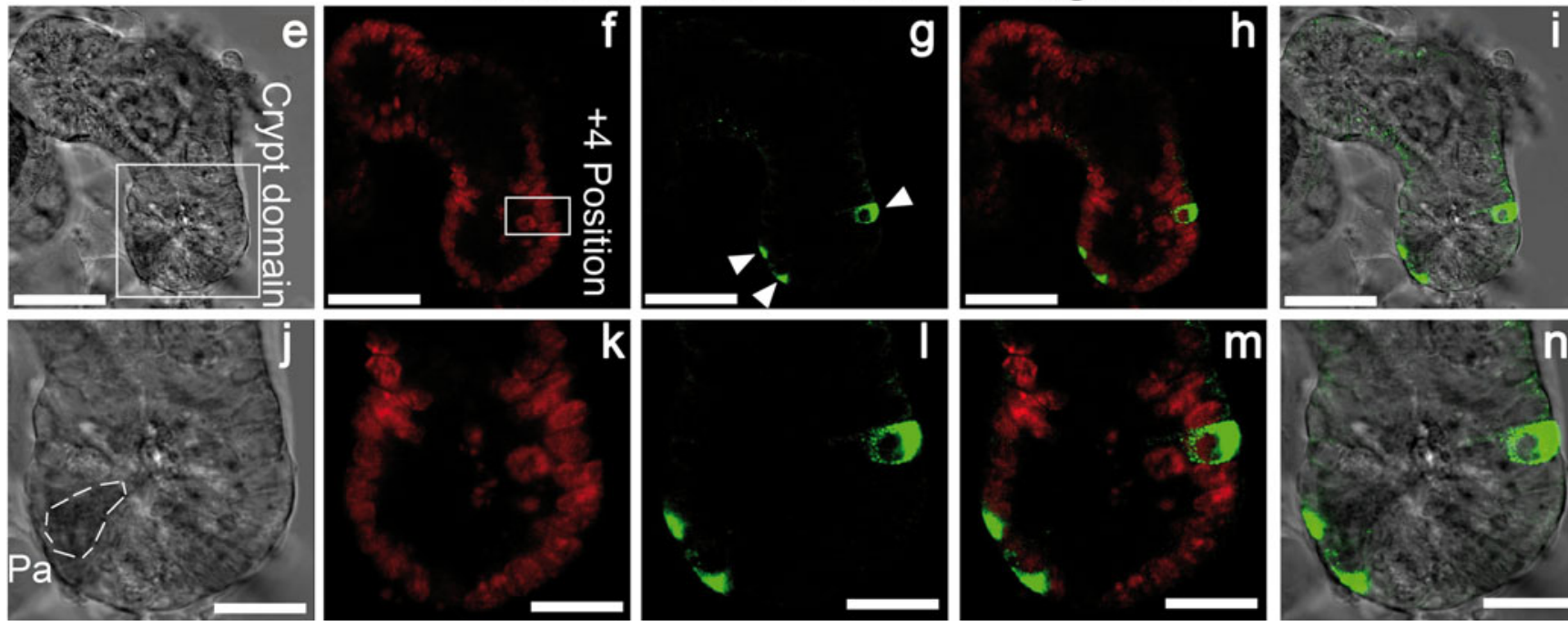

Fig. 1 Distribution of $\mathrm{CD}_{4} 4^{+}$cells within intestinal epithelium. a, b Immunohistochemical (IHC) staining for Lgr $5^{+}$ISCs (black dotted lines) in vivo. c, d IHC staining for $\mathrm{CD}_{4} 4^{+}$cells (black dotted lines) in vivo. a, c Magnification $\times 400$. Bars $50 \mu \mathrm{m}$. b, d Magnification $\times 1000$. Bars $20 \mu \mathrm{m}$. e-n Immunocytochemical (ICC) staining for $\mathrm{CD}_{4} 4^{+}$cells in vitro. $\mathbf{e}, \mathbf{j}$ Differential interference contrast (DIC) imaging. f, k Propidium iodide (PI) staining for nuclei. g, l Fluorescein isothiocyanate (FITC) for CD $44^{+}$cells (white arrowheads crypt cells strongly positive for CD44). h, m Overlay of PI image and FITC image. i, n Overlay of FITC image and DIC image. e-i Magnification $\times 200$. Bars $200 \mu \mathrm{m}$. j-n Magnification $\times 630$. Bars $100 \mu \mathrm{m}$ 


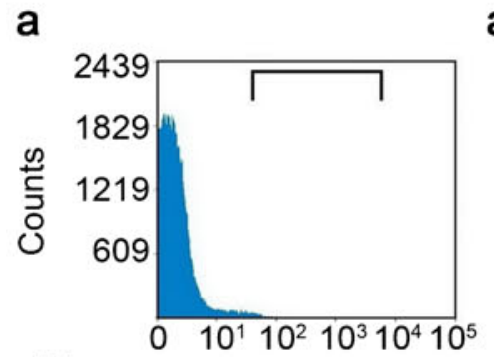

Phenotype of CD44+ cells

a"'

a'
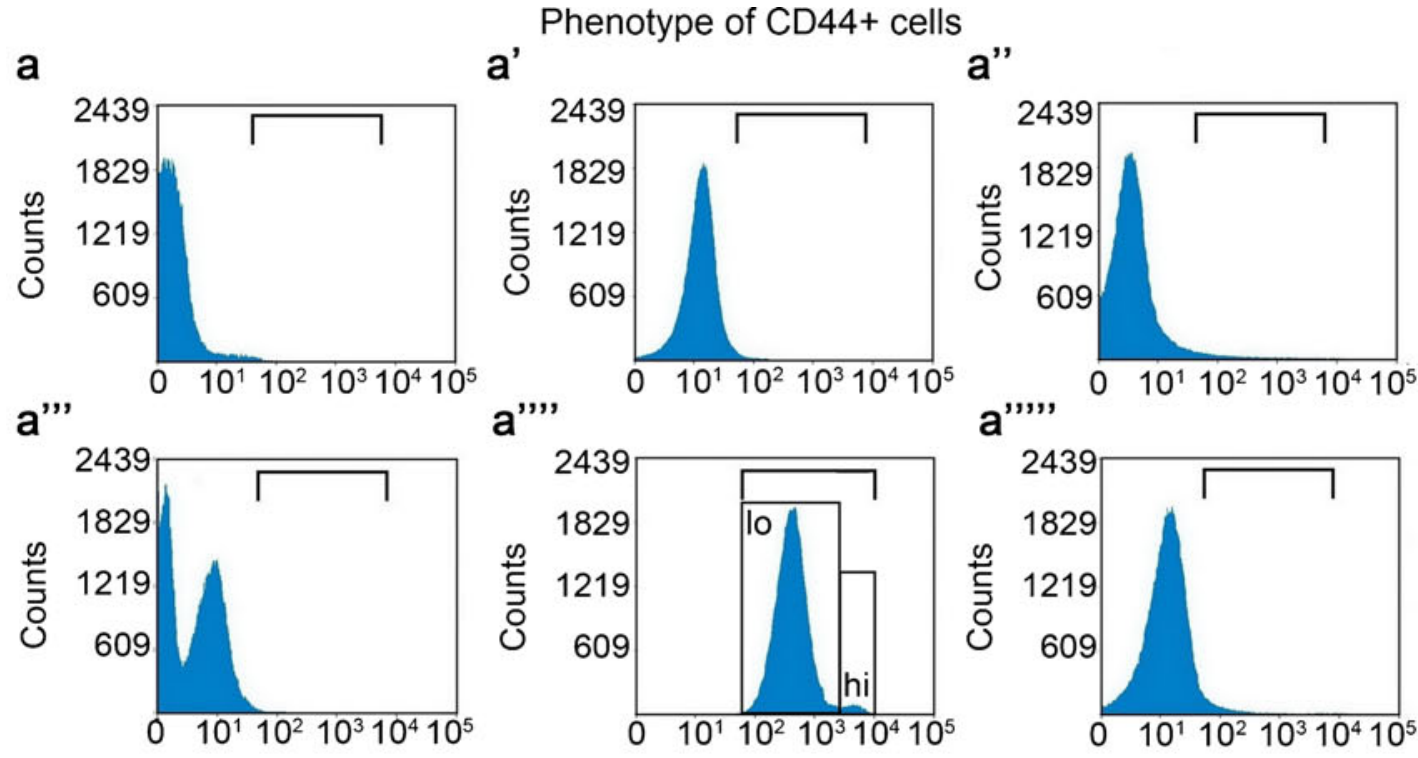

a"'"

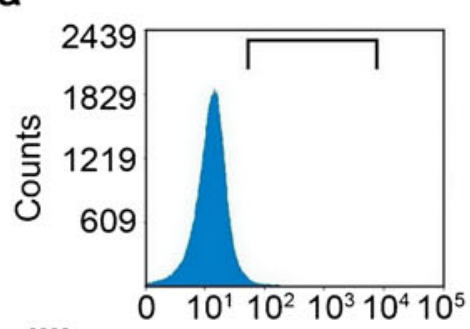

a"',
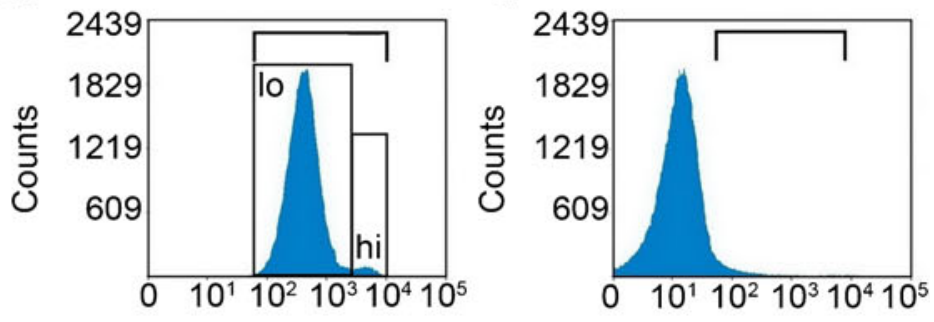

b

Development of a CD44+ ISC
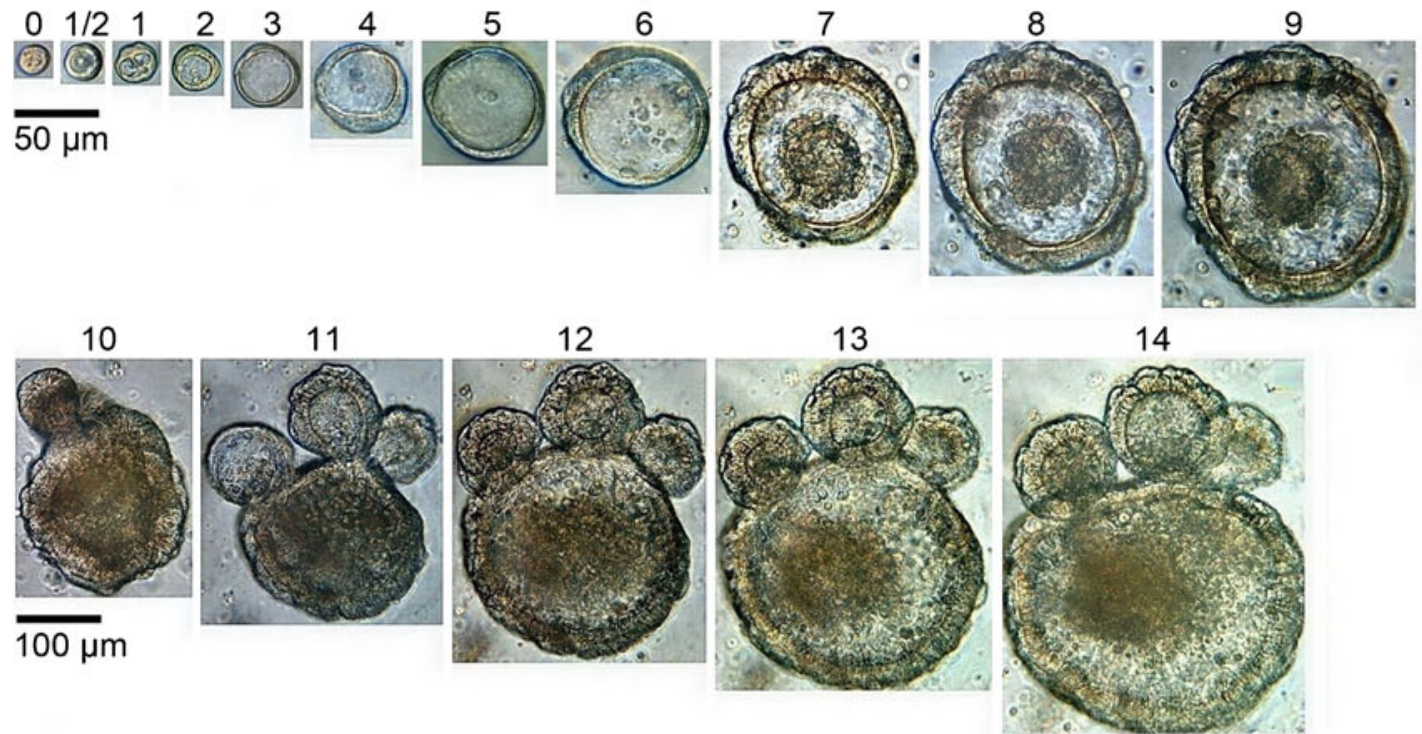

Comparison of colony-forming efficacy
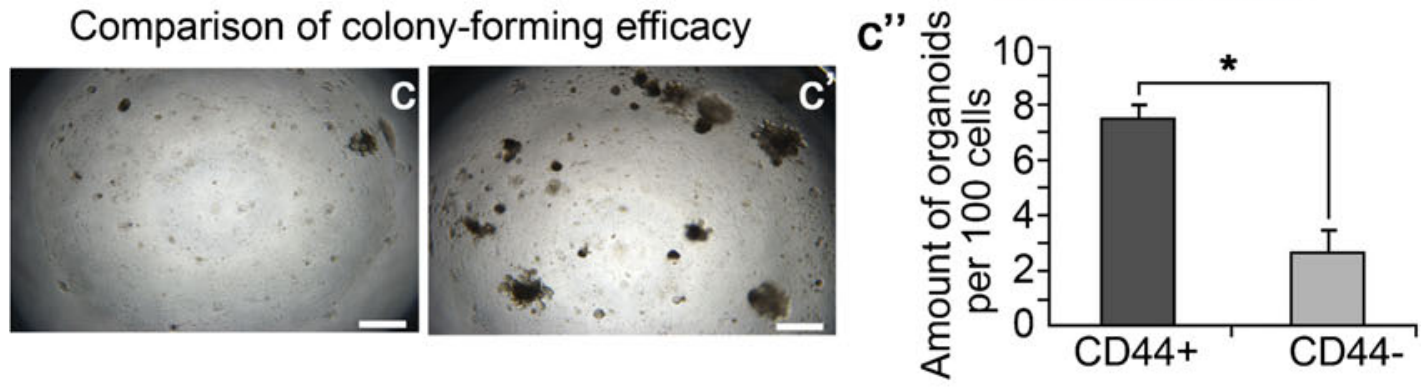

Differentiation analysis of CD44+ ISC
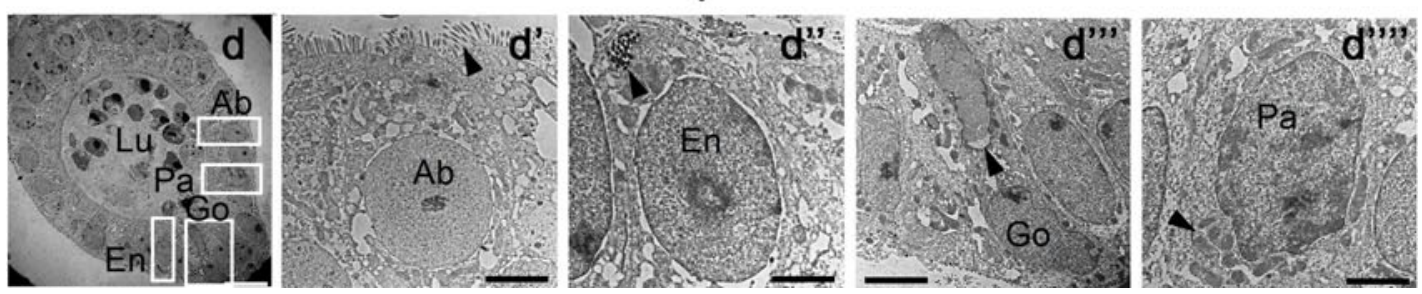
Fig. 2 Identification of $\mathrm{CD} 44^{+}$cells. a-a"'"' Fluorescence-activated cell sorting (FACS) analysis for cellular phenotype. a Isotype control, IgG2aphycoerythrin (PE). a' CD31-PE. a" CD34-PE. a" Isotype control, IgG2b-allophycocyanin (APC). a"" CD44-APC (lo low-positive for CD44, hi high-positive for CD44). a"'" CD45-APC. b Development of CD $44^{+}$ISC in 3D-culture system. Numbers represent days. Top Magnification $\times 400$. Bar $50 \mu \mathrm{m}$. Bottom Magnification $\times 200$. Bars $100 \mu \mathrm{m}$. c-c" Colony-forming efficacies of CD44 cells and CD44 cells. c CD44- cells in 3D-culture system for 14 days. c' CD44 ${ }^{+}$cells in 3D-culture system for 14 days. c, c' Magnification $\times 40$. Bars $500 \mu \mathrm{m}$. c" Comparision of colony-forming efficacy per 100 sorted cells seeded in one well of a 96-well plate. CD44- group in 48 wells; CD44 $4^{+}$group in 48 wells. Data represent means \pm SD of 48 independent measurements $(n=$ 48). Bars SD values. Paired $t$-test was used for data analysis. ${ }^{*} P \leq 0.05$ represents high significance $\left(\mathrm{CD} 44^{+}\right.$group versus $\mathrm{CD} 44^{-}$group). All experimental procedures were repeated twice. d-d" "Transmission electron microscope imaging of CD $44^{+}$ISC differentiation. CD $44^{+}$ISC were cultured in the 3D-system for 6 days and formed a cystic structure. $\mathbf{d}$ Cystic structure of a single CD $44^{+}$ISC-derived organoid at 6 days. Boxed areas are shown at higher magnification in d'-d"' ( $L u$ lumen). Magnification $\times 400$. Bar $50 \mu \mathrm{m}$. d' Absorptive cell $(A b)$. d" Endocrine cell $(E n)$. d"' Goblet cell $(\mathrm{Go})$. d"' Paneth cell $(\mathrm{Pa})$. Black arrowhead in d' indicates brush border. Black arrowheads in d"-d"' indicates granules. d'-d"' Magnification $\times 1500$. Bars $5 \mu \mathrm{m}$

$\mathrm{CD} 44^{+}$cells were seen to be able to form organoids after being cultured for 2 weeks (Fig. 2b). The colony-forming efficacy of CD $44^{+}$cells was significantly higher than that of the CD44controls with an increase of approximately three-fold (Fig. 2c-c"), indicating that the ISCs mainly consisted of a $\mathrm{CD} 44^{+}$population.

Next, we wished to determine whether the CD $44^{+}$crypt cells, which can develop into organoids, were ISCs. Of note, the "stemness" of the tissue-specific stem cells is defined as their rapid self-renewal and multi-lineage differentiation (Clevers 2013). By tracing the development of some CD $44^{+}$ crypt cells, we found that these cells constantly expanded their numbers during a period of 2 weeks (Fig. 2b), indicating that these cells were capable of dividing. Moreover, the CD $44^{+}$ crypt-cell-derived organoids contained all the functional cells of the epithelium of the small intestine, including absorptive cells, endocrine cells, goblet cells and Paneth cells, indicating that these CD $44^{+}$crypt cells were ISCs (Fig. 2d-d",", Supplemental Fig. S1).

\section{$\mathrm{CD}^{+} 4^{+}$ISCs resemble $\mathrm{CBC}$ stem cells}

When analyzing the purity of the microbead-sorted CD $44^{+}$ crypt cells, we found that these cells could be classified into two subpopulations: CD44 high-positive (termed CD $44^{\text {hi+ }}$ below) and CD44 low-positive (termed CD44 ${ }^{\text {low }}$ below; Fig. 2a"'"). Since the above results indicated that a population of ISCs was present in the CD $44^{+}$ crypt cells, we speculated that $\mathrm{CD} 44^{{ }^{\mathrm{hi}}{ }^{+}}$crypt cells were more similar to ISCs than CD44 ${ }^{\text {low }}+$ cells. To test this hypothesis, we sorted these two subpopulations by using the FACS technique (Fig. 3a-a"). Then, semi-quantitative RT-
PCR analysis was used to compare the expression of genes related to ISCs between these two pools of cells, with the CD44- population being set as the internal control. Relevant results showed that the ISC-related genes, including Lgr5, Bmi1, Hopx, Ascl2, Smoc2, Lrig1 and Rnf43, were significantly up-regulated with regard to their expressions in $\mathrm{CD} 44^{\mathrm{hi+}}$ crypt cells, whereas no significant differences were found in the expression of each of $m$ TERT and Prominin-1 between these two populations (Fig. 3b). On this basis, we tried to compare the organoid-forming capabilities between these two cell-populations. The results showed that the CD $44^{\text {hi+ }}$ crypt cells were capable of forming organoids during a period of 2 weeks culturing, whereas most of the CD $44^{\text {low+ }}$ cells could only form cell clusters in vitro (Fig. 3c, c'). All these data indicated that CD $44^{\text {hi+ }}$ crypt cells resembled CBC stem cells, whereas CD $44^{\text {low }}$ cells were similar to TA progenitors.

\section{Epithelial homeostasis in CD44 ${ }^{+}$ISC-derived organoids}

The growing mechanism of $\mathrm{Lgr}^{+} \mathrm{CBC}$ stem cells has been well investigated (Sato et al. 2009). In the present study, the apoptotic and proliferative activities were analyzed to determine the specific homeostasis in CD $44^{+}$ISC-derived organoids. In vivo, the apoptotic cells were mainly located at the top of villi, whereas the proliferative cells were arranged in the crypt domain (Fig. 4a-d). The organoids shared similar characteristics. As shown in Fig. $4 \mathrm{e}-\mathrm{g}$, the TUNEL analysis suggested that most of the apoptotic cells were located in the lumen of organoids, indicating that the apoptotic cells were shed from the villus domain. In addition, most Ki67-positive cells were merely located within the crypt domain indicating that the development of organoids was driven by the proliferation of ISCs and by the commitment of TA progenitors into functional epithelial cells (Fig. $4 \mathrm{~h}-\mathrm{j}$ ). In contrast to the typical structure of the villus-crypt axis in vivo, the organoids contained finger-like crypts and flat villi (Fig. 4k), as formed naturally and escaped from the compression caused by tissuetensions in vivo. Taken together, our present findings suggest that CD $44^{+}$ISC and CBC stem cells share similar homeostatic activities when they grow into organoids.

\section{Radiation-induced crypt death can be delayed by co-culturing with MSCs}

Intestinal epithelium represents a tissue of high radiosensitivity, which is partially attributable to some fast-cycled ISCs (Metcalfe et al. 2014). As mentioned above, ISCs are only located in the crypts and can drive the development of organoids in vitro. On this basis, we investigated the inhibitory effects of ionizing irradiation on organoid formation. Anoikis in single-isolated ISCs affects their abilities to form organoids in vitro (Sato et al. 2009). To avoid this, we used 
Fig. $3 \mathrm{CD}_{4} 4^{+}$ISCs resemble CBC stem cells. a-a" Strategy for sorting CD44- $\mathrm{CD}^{-} 4^{\text {low }}$ and $\mathrm{CD} 44^{\mathrm{hi+}}$ subpopulations by using the FACS technique $(R I$ determining the cell-zone, $R 2$ determining viable cells, $P I$ propidium iodide, $A P C$ allophycocyanin). b Semiquantitative reverse transcription (RT) followed by the polymerase chain reaction (PCR) for ISCrelated gene-expression in sorted cells. Fold expression values were normalized to the CD44 group. Data represent means $\pm \mathrm{SD}$ of six independent measurements $(n=$ 6). Bars indicate value of SD. The paired $t$-test was used for data analysis. ${ }^{*} P \leq 0.05$ represents high significance $\left(\mathrm{CD} 44^{\mathrm{hi}}{ }^{\mathrm{t}}\right.$ group versus $\mathrm{CD} 44^{\text {low }+}$ group); ${ }^{\$} P \leq$ 0.05 represents low significance (CD44 ${ }^{\text {hi+ }}$ group versus CD44 $4^{\text {low }+}$ group); $n s$ represents no statistic differences between the CD44 ${ }^{\text {hi+ }}$ group and $\mathrm{CD} 44^{\text {low }}{ }^{+}$group. $P$ values for Lgr 5, Bmil, Hopx, mTERT, Ascl2, Smoc2, Lrig1, Rnf43 and Prominin-1 are respectively $0.016,0.036,0.010$, 0.844, 0.007, 0.001, 0.041, 0.005 and 0.859 . c, c' Colony-forming efficacy of CD $44^{\text {low }}+$ and CD44 ${ }^{\mathrm{hi}+}$ cells in $3 \mathrm{D}$-culture system for 14 days. c CD $44^{\text {low }}$ group. c' $\mathrm{CD} 44^{\mathrm{hi}+}$ group. Magnification $\times 40$. Bars $500 \mu \mathrm{m}$

\section{Sorting strategy for CD44low and CD44hi cells}
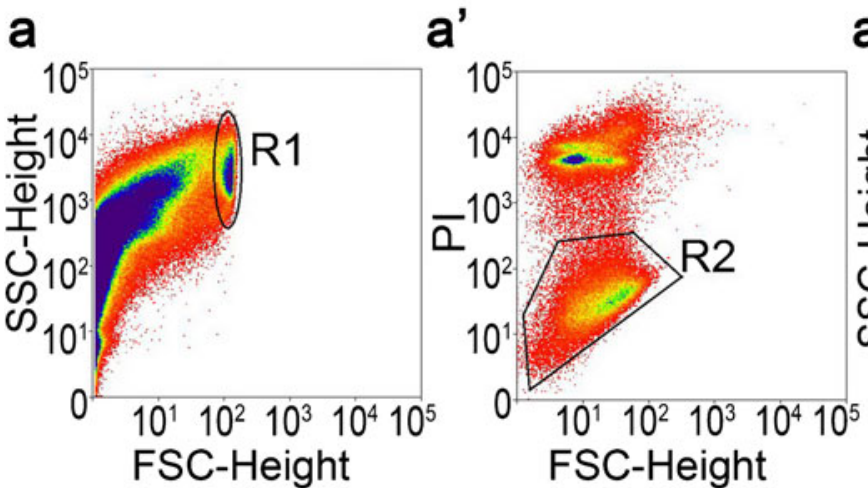

a"

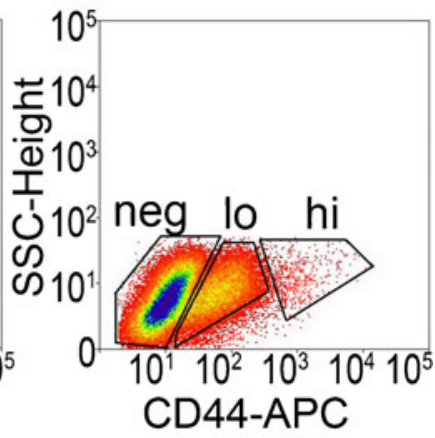

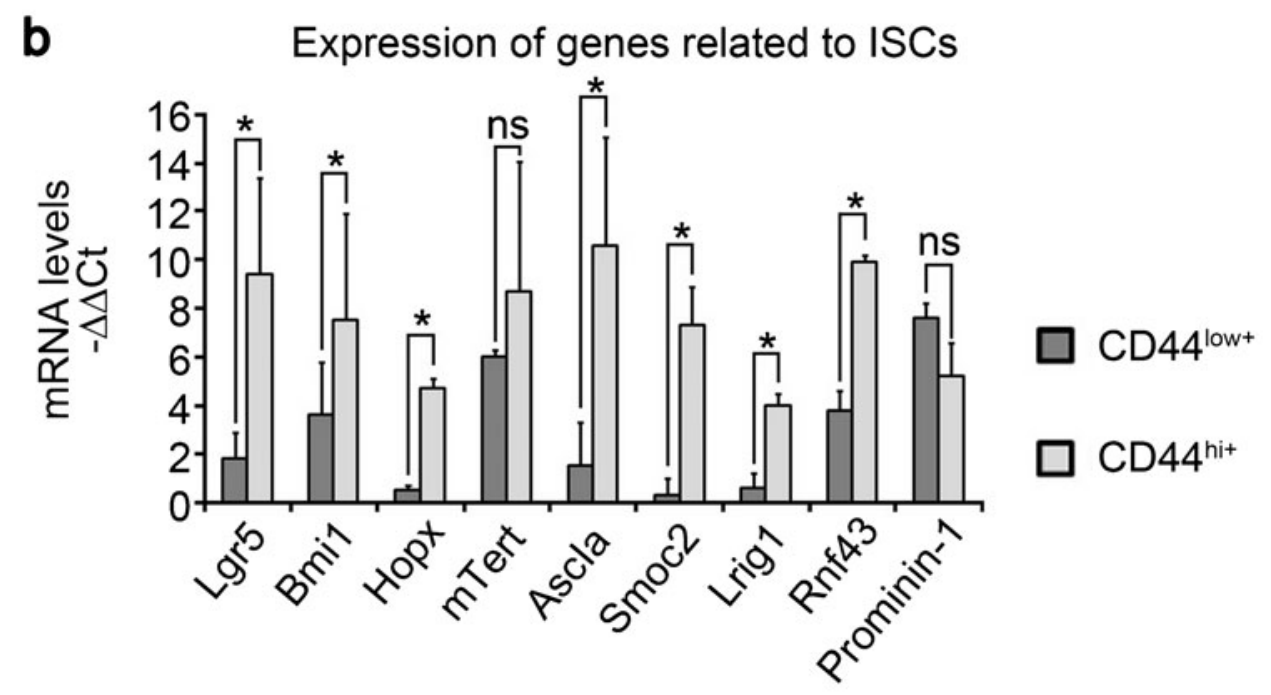

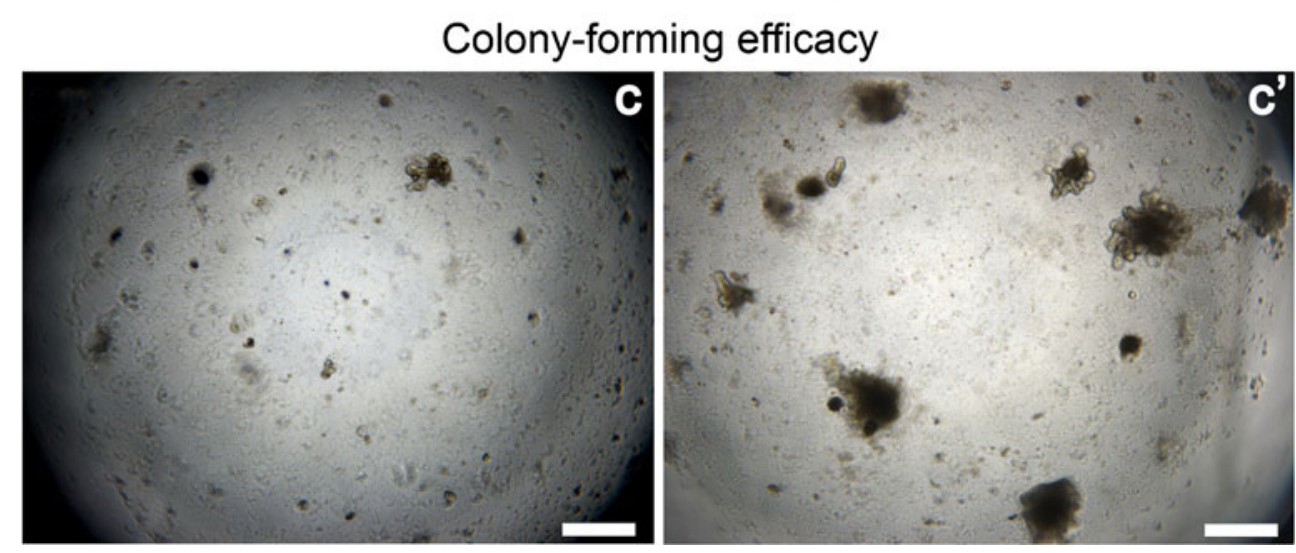

crypt fragments. A single dose of $5 \mathrm{~Gy}, 7.5 \mathrm{~Gy}, 10 \mathrm{~Gy}$, $12.5 \mathrm{~Gy}$, or 15 Gy was separately administered to the freshly isolated crypt fragments. Strikingly, the relevant results showed that the crypt fragments halted their growth and loosened their structures around 2 to 4 days post-irradiation (Fig. 5a), indicating that ionizing-irradiation-induced crypt death occurred irrespective of the radiation doses and that all supplements in the medium were insufficient to improve the resistance of crypts to ionizing irradiation.
Next, we tried to determine whether the MSCs were capable of limiting apoptosis in irradiated organoids, as our previous work had demonstrated that MSC infusion could promote epithelial regeneration in a rodent model of radiation-induced intestinal injury (Chang et al. 2013). To this end, the freshly isolated crypt fragments were induced to form organoids during the first 7 days (by using a plating density of 500 crypt fragments per well in a 24-well plate). Then, the organoids were separately irradiated at 5 Gy and 15 Gy and were then 
Fig. 4 Epithelial homeostasis in CD44 $4^{+}$ISC-derived organoid. a, b TUNEL staining for apoptotic cells in normal epithelium. c, d IHC staining of Ki67 for proliferative cells within normal epithelium. a, c Magnification $\times 200$. Bars $100 \mu \mathrm{m}$. b, d Magnification $\times 400$. Bars $50 \mu \mathrm{m}$. e-j Epithelial homeostasis in vitro. $\mathbf{e}-\mathbf{g}$ TUNEL staining for apoptotic cells in $\mathrm{CD}_{4} 4^{+}$ISCderived organoid. e DAPI staining (blue) for nuclei. f dUTPFITC (green) for apoptotic cells. $\mathbf{g}$ DAPI image merged with dUTPFITC image. Magnification $\times 100$. Bars $200 \mu \mathrm{m} . \mathbf{h}-\mathbf{j}$ ICC staining for proliferative cells in $\mathrm{CD} 44^{+}$ ISC-derived organoid. h DAPI staining for nuclei. i Ki67-FITC for proliferative cells. $\mathbf{j}$ DAPI image merged with Ki67-FITC image. Magnification $\times 200$. Bar $100 \mu \mathrm{m}$. k Representation of an organoid

\section{Epithelial homeostasis in vivo}
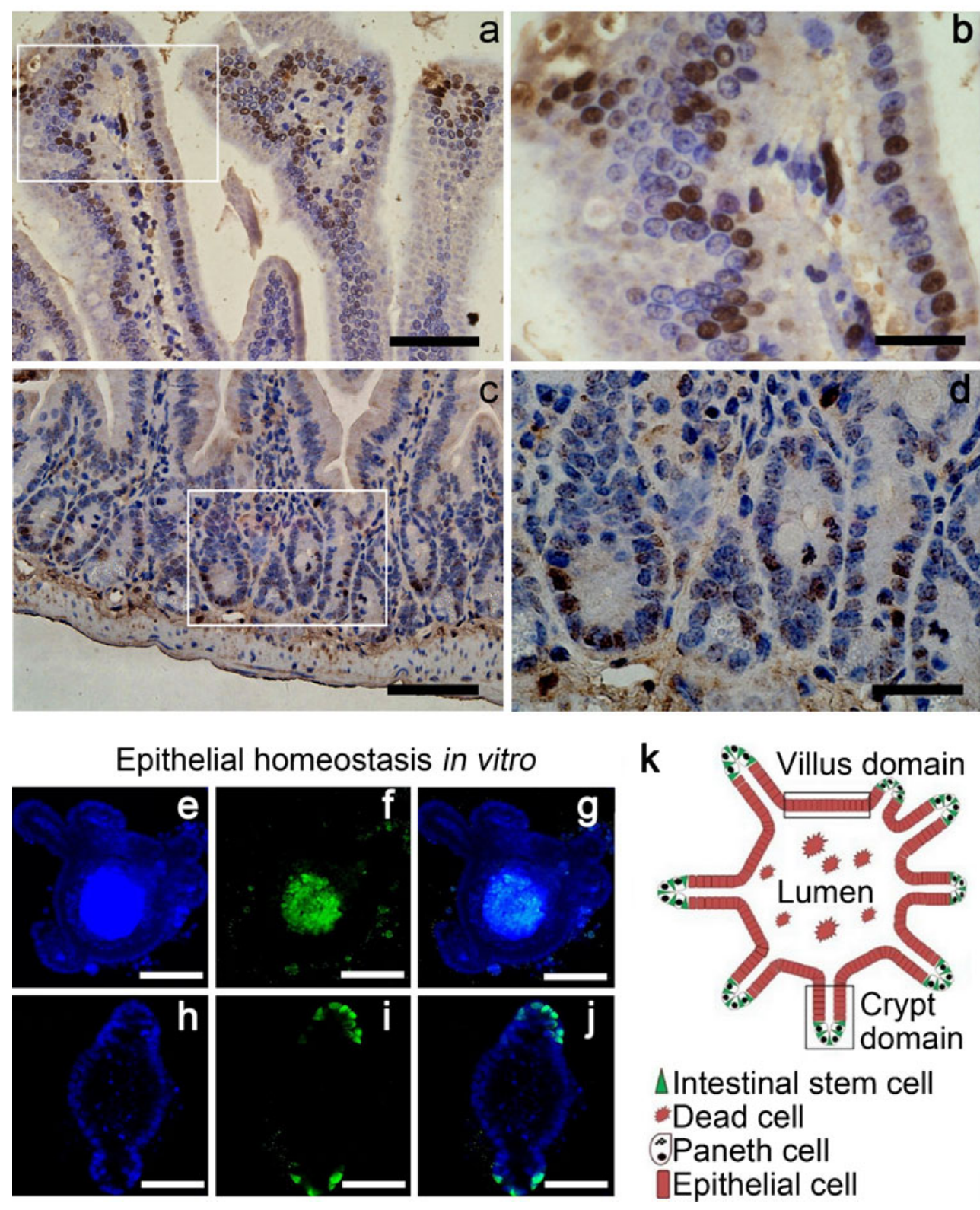

co-cultured immediately with human MSCs in a transwell system (bore diameter of upper mesh: $8 \mu \mathrm{m}$ ) at a ratio of 1:100. At $48 \mathrm{~h}$ post-irradiation, some MSCs were located next to the irradiated organoids (Fig. 5b-b") and the crypt domain in the organoids possessed fewer apoptotic cells than those receiving ionizing radiation alone (Fig. 5c). Meanwhile, a certain number of proliferative cells still existed in the irradiated crypt fragments, when co-culturing with MSCs (Fig. 5d, Supplemental Fig. S2). However, the proliferative activity within these crypts co-cultured with MSCs was decreased, whereas the apoptotic activity was swiftly increased at $72 \mathrm{~h}$ post-irradiation (data not shown), indicating that these crypts would still undergo radiation-induced death in spite of MSC intervention. Moreover, the proliferation in the crypt domain of irradiated organoids appeared to be related to the number of MSCs in the co-culture system (Supplemental Fig. S3). In addition, the MSCs in the co-culture system showed their proliferative potential together with morphological alterations from spindle-like shapes to elliptical shapes (Supplemental Figs. S4, S5). Proliferative cells in the crypt domain are characterized by their expression of Cd44 variant 6 (termed Cd44v6; Schmitt et al. 2015). Our findings showed that, upon intervention by MSCs, the expression of $C d 44 v 6$ still existed in crypt fragments at $48 \mathrm{~h}$ post-irradiation (Fig. 5e). By contrast, no $C d 44 v 6$ was detected in irradiated crypts, reflecting that ISCs and TA progenitors were nearly depleted. Although the exact duration of the delay in radiation-induced crypt death caused by MSC intervention was difficult to define, 


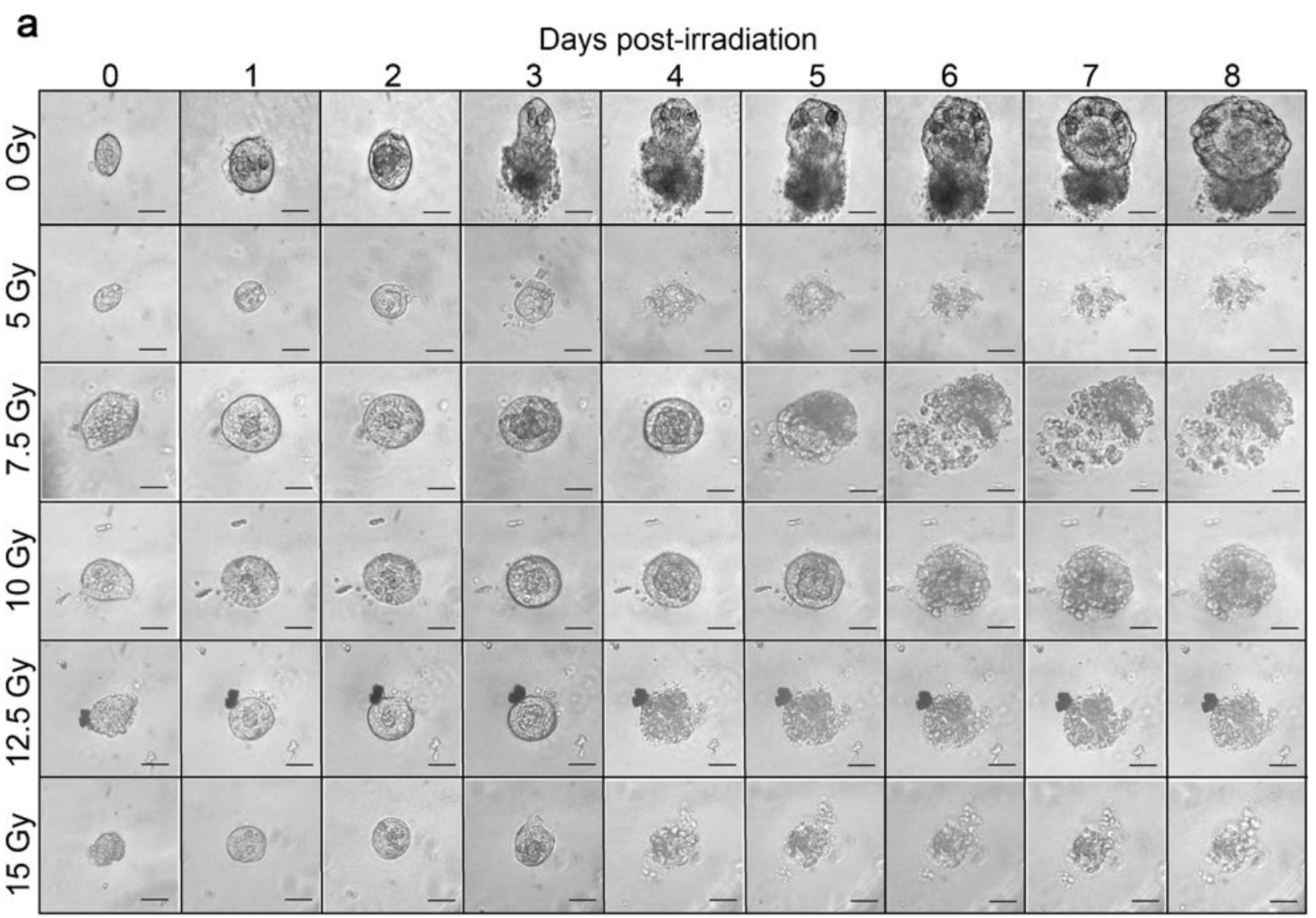

Migration of MSCs to irradiated organoids
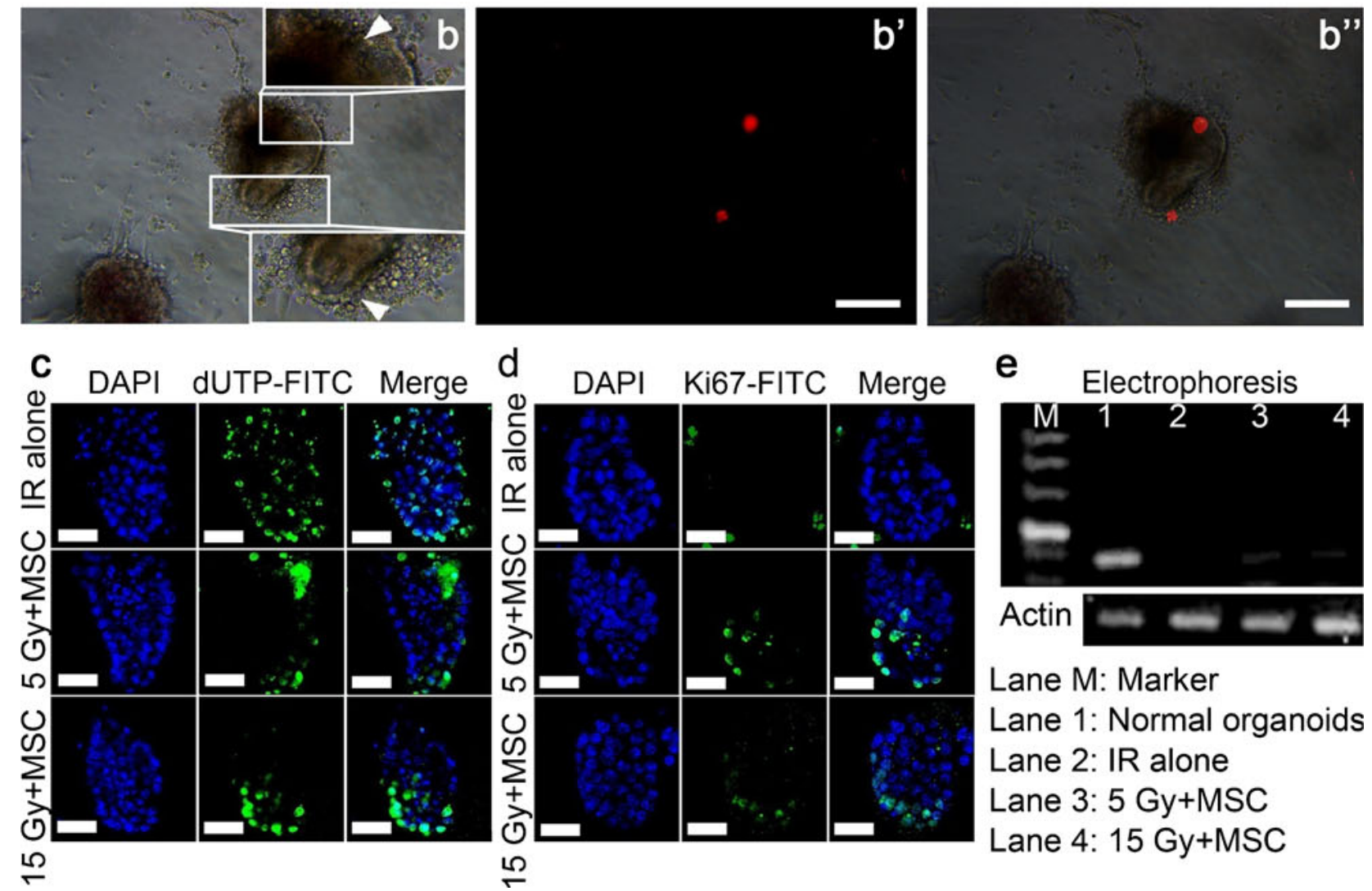

e Electrophoresis

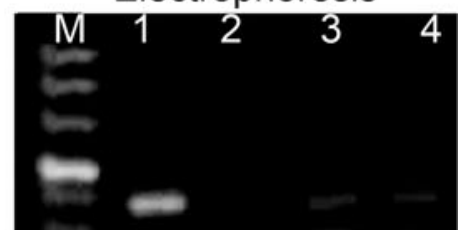

Actin $=0$

Lane M: Marker

Lane 1: Normal organoids Lane 2: IR alone

Lane 3: $5 \mathrm{~Gy}+\mathrm{MSC}$

Lane 4: $15 \mathrm{~Gy}+\mathrm{MSC}$

$\stackrel{20}{\sim}$

$\stackrel{20}{2}$ 
4 Fig. 5 Mensenchymal stem cells (MSCs) delay radiation-induced crypt death. a In vitro growth of crypt fragments during a period of 8 days postirradiation. Numbers represent days post-irradiation. Magnification $\times 400$. Bars $50 \mu \mathrm{m}$. b-b" Chemotactic property of MSCs in vitro. In a transwell experiment, MSCs were plated on the upper mesh of $12-\mu \mathrm{m}$ bore diameter. The organoids were plated on the lower plate by using Matrigel. At $48 \mathrm{~h}$ after co-culturing, MSCs migrated to the irradiated organoids. b Phase-contrast imaging for organoids (white arrowheads infiltrated MSCs). b' Fluorescent imaging for MSCs labeled with CMDil (a lipophilic marker). b" Blended image. Magnification $\times 200$. Bars $100 \mu \mathrm{m}$. c TUNEL staining for apoptotic cells within organoids. d ICC staining of Ki67 for proliferative cells within organoids. c, d Magnification $\times 630$. Bars $20 \mu \mathrm{m}$. e RT-PCR for $C d 44 v 6$ expression in organoids. Electrophoresis in $1.5 \%$ agarose gel ( $M$ marker, Lane 1 normal group, Lane 2 irradiation alone $[I R]$ group, Lane $35 \mathrm{~Gy}+\mathrm{MSC}$ group, Lane $415 \mathrm{~Gy}+\mathrm{MSC}$ group). Actin was used for the internal control

our results indicated that more irradiated crypts survived at $48 \mathrm{~h}$ upon co-culturing with MSCs than without them.

\section{Discussion}

In this study, we successfully isolated $\mathrm{CD} 44^{+}$ISCs from the small intestine of C57BL/6 mice and confirmed the "stemness" of the CD44 $4^{+}$ISCs by analyzing their capabilities including their self-expansion and multiple differentiation into functional cells within the epithelium in vitro. These results demonstrated that CD44 can be used for marking ISCs.

To our knowledge, a controversy concerning the location of ISCs has persisted for several years, because ISCs at different sites possess distinct characteristics, including their numbers in crypts, their radiosensitivities and the mechanism for parental DNA segregation into progeny during division (Schepers et al. 2011; Potten et al. 2002). Despite this, we confirmed that the ISCs are located within the crypt. The present results show that cells strongly positive for CD44 are mainly found within the crypts, both in vitro and in vivo, at the putative sites in which ISCs are located, including the crypt basement and the $4+$ position of the crypt. On this basis, we further attempted to isolate the $\mathrm{CD} 44^{+}$cells from the intestinal epithelium in order to seek evidence indicating that ISCs do indeed exist in this cell population.

Nowadays, the FACS technique is widely applied to sort CBC stem cells from C57BL/ $/ 6^{\text {lgr5-eGFP-IRES-CreERT2 }}$ reporter mice according to the gradient expression of the $\operatorname{Lgr} 5$ gene in crypts (Sato et al. 2009). To sort ISCs from wild-type mice, several strategies have been explored, including the use of a single antigen, such as CD24 (von Furstenberg et al. 2011) or EphB2 (Sato et al. 2011b) and combined antigens, such as CD24/Sox9 (Gracz et al. 2010), CD24/CD44 (Gracz et al. 2013) and CD24/CD44/CD166/GRP78/c-Kit (Wang et al. 2013). In the present study, the marker of CD44 was used to isolate ISCs by means of the microbead-based sorting technique. As indicated previously, the ISCs undergo apoptosis shortly after being detached from their niches, termed anoikis and the ROCK inhibitor, Y-27632 dihydrochloride, can be used to prevent anoikis in ISCs (Sato et al. 2009). For the FACS technique, the protection of ISCs against apoptosis by the supplementation of sufficient Y-27632 dihydrochloride in a sheath of liquid is difficult. In contrast, a relatively small system for ISC sorting can be achieved by using the microbead-based technique, ensuring that adequate Y-27632 dihydrochloride covers the entire sorting process and thus maintains the viability of ISCs. However, the microbead-based sorting technique is not as good as the FACS technique in distinguishing the expression levels of putative markers related to ISCs. Moreover, the FACS technique allows a combination of several markers during one single sorting process, which ensures the precise identification of ISCs.

The present study has demonstrated that ISCs exist in the $\mathrm{CD} 44^{+}$population through using a microbead-based technique. However, when analyzing the purity of the sorted cells, we also found that the $\mathrm{CD} 44^{+}$population can be classified into two subpopulations: CD $44^{\text {hi+ }}$ and CD $44^{\text {low }}$. Further analysis of the distribution of $\mathrm{CD} 44^{+}$cells in the epithelium revealed that the $\mathrm{CD} 44^{\mathrm{hi}+}$ cells are apt to be $\mathrm{CBC}$ stem cells rather than reserve ISCs at the 4+ position of the crypt. First, both the $C d 44$ gene and $\operatorname{Lgr} 5$ gene are targets of the $\mathrm{Wnt} / \beta$-catenin signaling pathway (Barker et al. 2007; Wielenga et al. 1999). Second, the proliferation of reserve ISCs is independent of the activating $\mathrm{Wnt} / \beta$-catenin signaling pathway (Barker et al. 2012). Third, nearly $10 \%$ of $\mathrm{Lgr}^{+}$ISCs are located at the $4+$ position of the crypt partially accounting for the CD $44^{\text {hi+ }}$ cells at this position (Barker et al. 2007). In our study, quantitative RT-PCR analysis also revealed that CD44 ${ }^{\text {hi+ }}$ cells express high levels of ISC-related genes, such as Lgr 5, Bmi 1, Hopx, Ascl2, Smoc2, Lrig1 and Rnf43. Several of these genes, including $\mathrm{Lgr} 5$, Ascl2, Smoc2 and Rnf43, have been reported to be highly expressed by $\mathrm{CBC}$ stem cells (Barker et al. 2007; Schepers et al. 2011; Koo et al. 2012; Muoz et al. 2012). Concerning the genes for marking the reserve ISCs, including Bmil, Lrig1, Hopx and mTERT, CBC stem cells also keep their expression of these genes (Muoz et al. 2012). However, our results have shown that the $m T E R T$ gene does not up-regulate its expression in CD $44^{\text {hi+ }}$ cells compared with CD44 $4^{\text {low }+}$ cells. As reported by Breault et al. (2008), only one single cell positive for mTERT can be found within $~ 157$ crypts, indicating the rare expression of the $m T E R T$ gene by crypt cells. Moreover, the mTERT gene is also expressed by TA progenitors (Barker et al. 2012), partially accounting for the lack of a significant difference between $\mathrm{CD} 44^{\mathrm{hi}+}$ cells and $\mathrm{CD} 44^{\text {low }}{ }^{\text {t }}$ cells in their $m T E R T$ expression. Similarly, no difference has been found between $\mathrm{CD} 44^{\text {low }}$ cells and $\mathrm{CD} 44^{\mathrm{hi}+}$ cells with regard to the expression of Prominin-1, which has been demonstrated to be highly expressed by TA progenitors (Snippert et al. 2009). Moreover, CD $44^{\text {low }}$ cells seldom expand their numbers to 
develop into organoids in vitro, as compared with CD44 ${ }^{\text {hi+ }}$ cells. This evidence suggests that TA progenitors mainly occur in the $\mathrm{CD} 44^{\text {low }+}$ subpopulation. Thus, the sorting of $\mathrm{CD}_{4} 4^{+}$cells can harvest $\mathrm{CBC}$ stem cells, which mainly exist in the $\mathrm{CD} 44^{\mathrm{hi}+}$ subpopulation.

In adult intestine, $\mathrm{CBC}$ stem cells are responsible for maintaining epithelial homeostasis mainly under the control of signaling pathways, including Wnt/ $\beta$-catenin, Ras/Raf/Mek/Erk, Notch and BMP/Smad (Sato and Clevers 2013). After their commitment into TA progenitors, these progenitors are devoted to differentiating into functional epithelial cells along the villus-crypt axis for replenishing dead cells. In the same way, the $\mathrm{CD} 44^{+}$ISC-derived organoids also retain the mechanism by which the proliferative cells within the crypt domain drive epithelial homeostasis. Within the $\mathrm{CD} 44^{+}$ISC-derived organoids, the proliferative cells are exclusively arranged in the crypt domain, whereas apoptotic cells are shed into the lumen. However, the organoids seem to be radiosensitive in vitro.

As described above, the $\mathrm{CD} 44^{+}$ISCs resemble $\mathrm{CBC}$ stem cells. However, the CBC stem cells are radiosensitive. Previous in vivo data have shown that a dose of only 0.01 Gy irradiation can initiate apoptosis in $10 \%$ of CBC stem cells, whereas the intestine can tolerate the depletion of such radiosensitive $\mathrm{CBC}$ stem cells by presenting no alteration in epithelial architecture (Metcalfe et al. 2014; Zhu et al. 2013). When the intestine receives 6 Gy to $12 \mathrm{~Gy}$, epithelial regeneration depends on the action of reserve ISCs converting into $\mathrm{CBC}$ stem cells, indicating the indispensability of $\mathrm{CBC}$ stem cells for epithelial regeneration (Metcalfe et al. 2014). In contrast to the above in vivo results, we found that the crypt fragments, receiving doses between 5 Gy and 15 Gy, will be dead within $\sim 4$ days, implying a rapid depletion in CBC stem cells and an absence of activated reserve ISCs. The reason probably lies in the presently used 3D-culture system, which lacks essential factors for maintaining the growth of reserve ISCs (Sato et al. 2009), because these ISCs are independent of Wnt-driven proliferation (Barker et al. 2012). Alternatively, the niches for ISCs are nearly destroyed following irradiation, because the mature epithelial cells are even more sensitive to ionizing irradiation than CBC stem cells (Hua et al. 2012). However, recent in vivo data suggest that Paneth cells, the niche cells for ISCs, will disappear from crypts when irradiated at a dose of 15 Gy (Metcalfe et al. 2014; Sato et al. 2011a, 2011b). The present results indicate that crypt death occurs irrespective of irradiating doses.

In order to protect the crypts against radiation-induced death, we attempted to culture MSCs with irradiated organoids, as our previous data had suggested that an infusion of MSCs could accelerate epithelial regeneration through increasing the number of reserve ISCs within irradiated intestine (Chang et al. 2013). The present results show that, although no preservation of architecture and ultimate death are noticed in irradiated organoids, the crypts in those irradiated organoids co-cultured with MSCs still present fewer apoptotic cells, whereas more proliferative cells are found within the crypt domain compared with the controls. Moreover, Cd44v6 expression is maintained in these irradiated organoids at $48 \mathrm{~h}$ after co-culturing with MSCs. As described above, $C d 44 v 6$ is uniquely expressed by proliferative cells within crypts, which undoubtedly contain ISCs and TA progenitors (Schmitt et al. 2015). In addition, recent data have suggested that the CD44 protein is capable of increasing the activity of the $\mathrm{Wnt} / \beta$ catenin signaling pathway through the regulation of the localization of low-density lipoprotein receptor-related protein 6 (LRP6) in the cell membrane (Schmitt et al. 2015). LRP6 is well documented as playing a critical role in the proliferation of ISCs. Mechanistically, the Wnt3 stimulates ISC proliferation mainly through its co-instantaneous binding to the LRP6 receptor and the extracellular end of the Frizzled receptor, an action that leads to the intracytoplasmic accumulation of $\beta$ catenin for pulsing on the expression of the $c-M y c$ gene (Sato and Clevers 2013; Bettess et al. 2005). On this basis, we speculate that the down-regulation of $C d 44 v 6$ will hamper the Paneth cell (a source of Wnt3)-initiated proliferation of ISCs in irradiated organoids because of the low activity of the Wnt/ $\beta$-catenin signaling pathway, which subsequently results in the down-regulation in $\operatorname{Lgr} 5$ expression (Sato et al. 2011a, 2011b). On this basis, the R-spondin1 hardly amplifies the responses of ISCs to Wnt3 -initiated proliferation because of the lack of Lgr5 receptors on the cell membrane (Yui et al. 2012; Binnerts et al. 2007). In contrast, when co-cultured with MSCs, irradiated organoids can preserve their Cd44v6 expression, indicating that proliferative cells still exist within irradiated crypts. However, epithelial homeostasis in irradiated organoids cannot be maintained by coculturing with MSCs. To some extent, the MSCs competitively absorb nutrients from the medium for their selfexpansion; this is also harmful for the growth of irradiated organoids.

In this study, the chemotactic property of MSCs was also investigated through transwell experiments. MSCs are observed around organoids at $48 \mathrm{~h}$ post-irradiation, compared with the controls (data not shown). Additionally, the MSCs present pie-like shapes in the medium for organoid growth, whereas their self-expanding ability is maintained in this medium. However, we have not evaluated any alterations in the properties of MSCs, such as their phenotype and multilineaged differentiation. On this basis, whether the medium for organoid growth can alter the secreting profile of MSCs remains unknown. Nevertheless, MSCs are known to be potent in preventing cell apoptosis through autocrine/paracrine actions. For example, cytokines including hepatocyte growth factor (HGF), prostaglandin E2 (PGE2), insulin-like growth factor-1 (IGF-1) and basic fibroblast growth factor (bFGF), are reported to be capable of enhancing the resistance of 
ISCs to ionizing irradiation predominantly through increasing the activity of the PI3K/Akt signaling pathway (Binnerts et al. 2007; Todaro et al. 2014; Tessner et al. 2004; Qiu et al. 2010). Collectively, the present data suggest that MSCs can delay crypt death but cannot maintain epithelial homeostasis. The detailed action of MSCs in delaying crypt death deserves further investigation.

In conclusion, CD44 can be used for marking ISCs and CD44 ${ }^{+}$ISCs resemble CBC stem cells. To some extent, MSCs can increase the radioresistance of the epithelium in vitro.

Author contributions Li-Xian Wang provided technical assistance during the sorting of the CD44 $4^{+}$crypt cells. Prof. Jin Wang revised the manuscript.

\section{Compliance with ethical standards}

Conflict of interests No competing conflicts of interest exist.

Open Access This article is distributed under the terms of the Creative Commons Attribution 4.0 International License (http:// creativecommons.org/licenses/by/4.0/), which permits unrestricted use, distribution, and reproduction in any medium, provided you give appropriate credit to the original author(s) and the source, provide a link to the Creative Commons license, and indicate if changes were made.

\section{References}

Barker N, van Es JH, Kuipers J, Kujala P, van den Born M, Cozijnsen M, Haegebarth A, Korving J, Begthel H, Peters PJ, Clevers H (2007) Identification of stem cells in small intestine and colon by marker gene Lgr5. Nature 449:1003-1007

Barker N, van Oudenaarden A, Clevers H (2012) Identifying the stem cell of the intestinal crypt: strategies and pitfalls. Cell Stem Cell 11:452460

Bettess MD, Dubois N, Murphy MJ, Dubey C, Roger C, Robine S, Trumpp A (2005) c-Myc is required for the formation of intestinal crypts but dispensable for homeostasis of the adult intestinal epithelium. Mol Cell Biol 25:7868-7878

Binnerts ME, Kim KA, Bright JM, Patel SM, Tran K, Zhou M, Leung JM, Liu Y, Lomas WE 3rd, Dixon M, Hazell SA, Wagle M, Nie WS, Tomasevic N, Williams J, Zhan X, Levy MD, Funk MD, Abo A (2007) R-Spondin1 regulates Wnt signaling by inhibiting internalization of LRP6. Proc Natl Acad Sci U S A 104:14700-14705

Breault DT, Min IM, Carlone DL, Farilla LG, Ambruzs DM, Henderson DE, Algra S, Montgomery RK, Wagers AJ, Hole N (2008) Generation of mTert-GFP mice as a model to identify and study tissue progenitor cells. Proc Natl Acad Sci U S A 105:10420-10425

Chang P, Qu Y, Liu Y, Cui S, Zhu D, Wang H, Jin X (2013) Multitherapeutic effects of human adipose-derived mesenchymal stem cells on radiation-induced intestinal injury. Cell Death Dis 4:e685

Clevers H (2013) Stem cells: a unifying theory for the crypt. Nature 495: $53-54$

Gracz AD, Ramalingam S, Magness ST (2010) Sox9 expression marks a subset of CD24-expressing small intestine epithelial stem cells that form organoids in vitro. Am J Physiol Gastrointest Liver Physiol 298:G590-G600

Gracz AD, Fuller MK, Wang F, Li L, Stelzner M, Dunn JC, Martin MG, Magness ST (2013) Brief reports: CD24 and CD44 mark human intestinal epithelial cell population with characteristics of active and facultative stem cells. Stem Cells 31:2024-2030

Hua G, Thin TH, Feldman R, Haimovitz-Friedman A, Clevers H, Fuks Z, Kolesnick R (2012) Crypt base columnar stem cells in small intestines of mice are radioresistant. Gastroenterology 143:1266-1276

Jung P, Sato T, Merlos-Suárez A, Barriga FM, Iglesias M, Rossell D, Auer H, Gallardo M, Blasco MA, Sancho E, Clevers H, Batlle E (2011) Isolation and in vitro expansion of human colonic stem cells. Nat Med 17:1225-1227

Koo BK, Spit M, Jordens I, Low TY, Stange DE, van de Wetering M, van Es JH, Mohammed S, Heck AJ, Maurice MM, Clevers H (2012) Tumour suppressor RNF43 is a stem-cell E3 ligase that induces endocytosis of Wnt receptors. Nature 488:665-669

Li L, Clevers H (2010) Coexistence of quiescent and active adult stem cells in mammals. Science 327:542-545

Metcalfe C, Kljavin NM, Ybarra R, de Sauvage FJ (2014) Lgr5+ stem cells are indispensable for radiation-induced intestinal regeneration. Cell Stem Cell 14:149-159

Morin PJ, Sparks AB, Korinek V, Barker N, Clevers H, Vogelstein B, Kinzler KW (1997) Activation of beta-catenin-Tcf signaling in colon cancer by mutations in beta-catenin or APC. Science 275:17871790

Muoz J, Stange DE, Schepers AG, van de Wetering M, Koo BK, Itzkovitz S, Volckmann R, Kung KS, Koster J, Radulescu S, Myant K, Versteeg R, Sansom OJ, van Es JH, Barker N, van Oudenaarden A, Mohammed S, Heck AJ, Clevers H (2012) The Lgr5 intestinal stem cell signature: robust expression of proposed quiescent " +4 " cell markers. EMBO J 31:3079-3091

Potten CS, Owen G, Booth D (2002) Intestinal stem cells protect their genome by selective segregation of template DNA strands. J Cell Sci 115:2381-2388

Qiu W, Leibowitz B, Zhang L, Yu J (2010) Growth factors protect intestinal stem cells from radiation-induced apoptosis by suppressing PUMA through the PI3K/AKT/p53 axis. Oncogene 29:1622-1632

Sato T, Clevers H (2013) Growing self-organizing mini-guts from a single intestinal stem cell: mechanism and application. Science 340:1190 1194

Sato T, Vries RG, Snippert HJ, van de Wetering M, Barker N, Stange DE, van Es JH, Abo A, Kujala P, Peters PJ, Clevers H (2009) Single Lgr5 stem cells build crypt-villus structures in vitro without a mesenchymal niche. Nature 459:262-265

Sato T, Stange DE, Ferrante M, Vries RG, van Es JH, van den Brink S, van Houdt WJ, Pronk A, van Gorp J, Siersema PD, Clevers H (2011a) Long-term expansion of epithelial organoids from human colon, adenoma, adenocarcinoma, and Barrett's epithelium. Gastroenterology 141:1762-1772

Sato T, van Es JH, Snippert HJ, Stange DE, Vries RG, van den Born M, Barker N, Shroyer NF, van de Wetering M, Clevers H (2011b) Paneth cells constitute the niche for Lgr5 stem cells in intestinal crypts. Nature 469:415-418

Schepers AG, Vries R, van den Born M, van de Wetering M, Clevers H (2011) Lgr5 intestinal stem cells have high telomerase activity and randomly segregate their chromosomes. EMBO J 30:1104-1109

Schmitt M, Metzger M, Gradl D, Davidson G, Orian-Rousseau V (2015) CD44 functions in Wnt signaling by regulating LRP localization and activation. Cell Death Differ 22:677-689

Snippert HJ, van Es JH, van den Born M, Begthel H, Stange DE, Barker N, Clevers H (2009) Prominin-1/CD133 marks stem cells and early progenitors in mouse small intestine. Gastroenterology 136:21872194

Snippert HJ, van der Flier LG, Sato T, van Es JH, van den Born M, Kroon-Veenboer C, Barker N, Klein AM, van Rheenen J, Simons BD, Clevers H (2010) Intestinal crypt homeostasis results from neutral competition between symmetrically dividing Lgr5 stem cells. Cell 143:134-144 
Tessner TG, Muhale F, Riehl TE, Anant S, Stenson WF (2004) Prostaglandin E2 reduces radiation-induced epithelial apoptosis through a mechanism involving AKT activation and bax translocation. J Clin Invest 114:1676-1685

Tian H, Biehs B, Warming S, Leong KG, Rangell L, Klein OD, de Sauvage FJ (2011) A reserve stem cell population in small intestine renders Lgr5-positive cells dispensable. Nature 478:255-259

Todaro M, Gaggianesi M, Catalano V, Benfante A, Iovino F, Biffoni M, Apuzzo T, Sperduti I, Volpe S, Cocorullo G, Gulotta G, Dieli F, De Maria R, Stassi G (2014) CD44v6 is a marker of constitutive and reprogrammed cancer stem cells driving colon cancer metastasis. Cell Stem Cell 14:342-356

van der Flier LG, Clevers H (2009) Stem cells, self-renewal, and differentiation in the intestinal epithelium. Annu Rev Physiol 71:241-260

van Es JH, Sato T, van de Wetering M, Lyubimova A, Nee AN, Gregorieff A, Sasaki N, Zeinstra L, van den Born M, Korving J, Martens AC, Barker N, van Oudenaarden A, Clevers H (2012) Dll1+ secretory progenitor cells revert to stem cells upon crypt damage. Nat Cell Biol 14:1099-1104

Van Limbergen J, Geddes K, Henderson P, Russell RK, Drummond HE, Satsangi J, Griffiths AM, Philpott DJ, Wilson DC (2015) Paneth cell marker CD24 in NOD2 knockout organoids and in inflammatory bowel disease (IBD). Gut 64:353-354

von Furstenberg RJ, Gulati AS, Baxi A, Doherty JM, Stappenbeck TS, Gracz AD, Magness ST, Henning SJ (2011) Sorting mouse jejuna epithelial cells with CD24 yields a population with characteristics of intestinal stem cells. Am J Physiol Gastrointest Liver Physiol 300: G409-G417 von Furstenberg RJ, Buczacki SJ, Smith BJ, Seiler KM, Winton DJ, Henning SJ (2014) Side population sorting separates subfractions of cycling and non-cycling intestinal stem cells. Stem Cell Res 12: 364-375

Wang F, Scoville D, He XC, Mahe MM, Box A, Perry JM, Smith NR, Lei NY, Davies PS, Fuller MK, Haug JS, McClain M, Gracz AD, Ding S, Steizner M, Dunn JC, Magness ST, Wong MH, Martin MG, Helmrath M, Li L (2013) Isolation and characterization of intestinal stem cells based on surface marker combinations and colonyformation assay. Gastroenterology 145:383-395

Wielenga VJ, Smits R, Korinek V, Smit L, Kielman M, Fodde R, Clevers H, Pals ST (1999) Expression of CD44 in Apc and Tcf mutant mice implies regulation by the WNT pathway. Am J Pathol 154:515-523

Yui S, Nakamura T, Sato T, Nemoto Y, Mizutani Y, Zheng X, Ichinose S, Nagaishi T, Okamoto R, Tsuchiya K, Clevers H, Watanabe M (2012) Functional engraftment of colon epithelium expanded in vitro from a single adult Lgr5+ stem cell. Nat Med 18:618-623

Zeilstra J, Joosten SP, Dokter M, Verwiel E, Spaargaren M, Pals ST (2008) Deletion of the WNT target and cancer stem cell marker CD44 in Apc(Min/+) mice attenuates intestinal tumorigenesis. Cancer Res 68:3655-3661

Zeilstra J, Joosten SP, van Andel H, Tolg C, Berns A, Snoek M, van de Wetering M, Spaargaren M, Clevers H, Pals ST (2014) Stem cell $\mathrm{CD} 44 \mathrm{v}$ isoforms promote intestinal cancer formation in $\mathrm{Apc}(\mathrm{min})$ mice downstream of Wnt signaling. Oncogene 33:665-670

Zhu Y, Huang YF, Kek C, Bulavin DV (2013) Apoptosis differently affects lineage tracing of Lgr5 and Bmil intestinal stem cell population. Cell Stem Cell 12:298-303 